\title{
Utilizing the Chesapeake Bay as a Basis for a Place-based Multi-component Project to Attain Earth Systems Engineering Course Objectives
}

\section{Dr. Bradley A. Striebig, James Madison University}

Dr. Striebig is a founding faculty member and first full professor in the Department of Engineering at James Madison University. Dr. Striebig came to the JMU School of from Gonzaga University where he developed the WATER program in cooperation with other faculty members. Dr. Striebig is also the former Head of the Environmental Technology Group at Penn State's Applied Research Laboratory. In addition to Dr' Striebig's engineering work, he is also a published freelance photographer who has works with local and international NGOs. Dr. Striebig was the founding editor of the Journal of Engineering for Sustainable Development and an assistant editor for the Journal of Green Building. 


\section{Utilizing the Chesapeake Bay as a Basis for a Place-based Multi-component Project in Earth Systems Engineering}

A systems engineering course is required by all engineering students for the completion of the undergraduate general engineering degree. This paper discusses the implementation of a semester-long, placed-based earth systems engineering course. This paper employs a mixedmethods assessment of the course that includes seven placed-based learning assessments, examples of student work, and a summary of student perceptions of the course.

The systems engineering course during their fourth year of study. Students entering their fourth year have typically completed courses in statics and dynamics, fluid dynamics, thermodynamics, materials, and instrumentation. This is the first exposure to systems engineering for students in the general engineering program. The following description summarizes the course and requirements:

This course focuses on the concepts of systems thinking and analysis for complex engineered systems. Students will develop basic knowledge and tools to identify a system, decompose it into parts, define interactions, perform analysis and apply control measures if necessary. Application of computational tools and mathematical modeling will be emphasized.

The interactions between man-made infrastructure and nature systems are complex and changing at the greatest rate in human history. These interactions significantly impact human development, human infrastructure and ecological systems. ${ }^{1,2,3,16,21}$ Engineering infrastructure must be more resilient due to the changing climate and future resource limitations. Systems engineering concepts can be introduced to illustrate how these systems interact - however, few environmental and human systems interactions are sufficiently described scientifically to allow for undergraduate curriculum development. ${ }^{10,11}$ Furthermore, it is challenging to develop the prerequisite knowledge in students to understand complex systems. The Chesapeake Bay Watershed, which has been studied for many decades and is also the home to students participating in the course, was chosen to develop a place-based, multi-component project in earth systems engineering. The course capitalizes on the student's knowledge and curiosity about the place in which they live.

The Chesapeake Bay Watershed is complex, extremely large, and consists of multi-variable systems that are difficult to define and model using simple singular-variable engineering analysis. This course utilized a place-based pedagogy to help relate these complex ideas to students' interests and existing knowledge. Place-based pedagogy is described by Gruenewald as "a community-based effort to reconnect the process of education, enculturation, and human development to the well-being of community life." Place-based pedagogy has the potential to help engage and deepen students understanding with related content. "Place-based science teaching focuses on local and regional environments and synthesizes different ways of knowing them, leveraging the senses of place of students and teachers. Place-based teaching has been advocated for its relevance and potential to attract underrepresented groups to science." 19 
The proposed curriculum was developed based on the complex and scientifically well-researched Chesapeake Bay Watershed, in which the college is located and greater than 95 percent of participating students are permanent residents. The course also reflects other common placebased characteristics, including a broad philosophy of understanding critical to earth systems engineering and a connection to the self and the community-based problem students were required to study. Place-based pedagogy also helps to incorporate sustainability concepts into a math-intensive systems engineering course. ${ }^{28}$ "Pedagogy of place challenges all educators to reflect on the relationship between the kind of education they pursue and the kind of places we inhabit and leave behind for future generations." 12

The course content is built upon the description of Earth Systems Engineering as described by Michael E. Gorman who developed an Earth Systems Engineering course in the department of Systems Engineering at the University of Virginia and concepts promoted by Industrial Ecologist Bradden Allenby. ${ }^{1,210,11}$ Other influential work that contributed to the curriculum includes the case study on the Florida Everglades Restoration Project, the NASA Earth Science Enterprise Plan, and course and curricula descriptions of Columbia University's Earth and Environmental

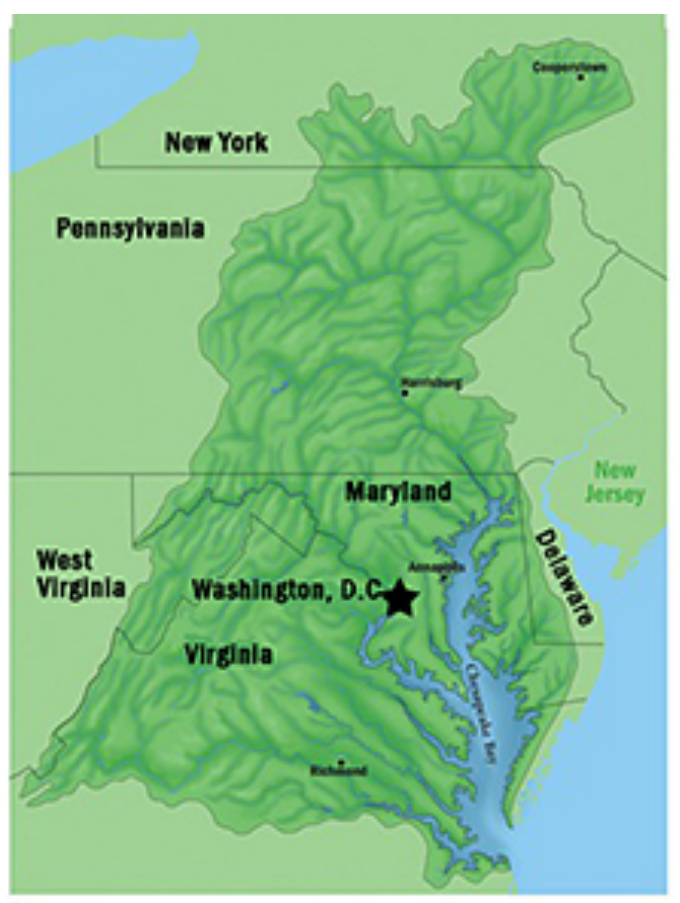
Engineering Program, The Center for Earth Systems Engineering and Management at Arizona State University, Cornell University's Science of Earth Systems major, the University of New Hampshire's Institute for the Study of Earth, Oceans and Space, and the Center for Integrated Earth System Science at the University of Texas at Austin. $5,6,14,17$

Resources for modeling the Chesapeake Bay were developed from various peer-reviewed literature sources and information reported and compiled by the Chesapeake By Foundation, the US Environmental Protection Agency, NASA, NOAA, the Chesapeake Bay Environmental Observatory, and the Chesapeake Community Modeling Program. $4,7,8,9,14,15,17,24,25,26,27$

Figure 1: The Chesapeake Bay Watershed as it spans six states and the District of Columbia. (http://www.cbf.org/image/blueprint-history-chesapeake-bay-watershed-map.jpg)

The place-based project was broken into seven stepwise assignments that encouraged students to identify subjects within the Chesapeake Bay that were of personal interest to them. Students then developed and proposed system-based problems that were defined and refined as the course proceeded. The course objective and related ABET outcomes are shown in Table 1. 
Table 1: ABET and student learning objectives

\begin{tabular}{|l|l|}
\hline 1. Articulate and apply the basic concepts associated with systems analysis. & $\mathrm{a}$ \\
\hline 2. Identify and define the inputs, outputs, parts of system, and interactions. & $\mathrm{e}$ \\
\hline 3. Develop system representations at multiple levels of fidelity. & $\mathrm{a}$ \\
\hline 4. Develop mathematical models for analysis of system. & $\mathrm{a}$ \\
\hline 5. Evaluate and characterize system performance. & $\mathrm{k}$ \\
\hline 6. Appropriately use modeling software tools for analysis. & $\mathrm{k}$ \\
\hline 7. Identify and evaluate trade-offs to make informed decisions. & $\mathrm{c}$ \\
\hline 8. Synthesize and apply systems thinking, principles, and tools to complex systems. & $\mathrm{c}$ \\
\hline
\end{tabular}

The course topics covered each week and how they align to the course outcomes are shown in Figure 2.

Topic Sequence

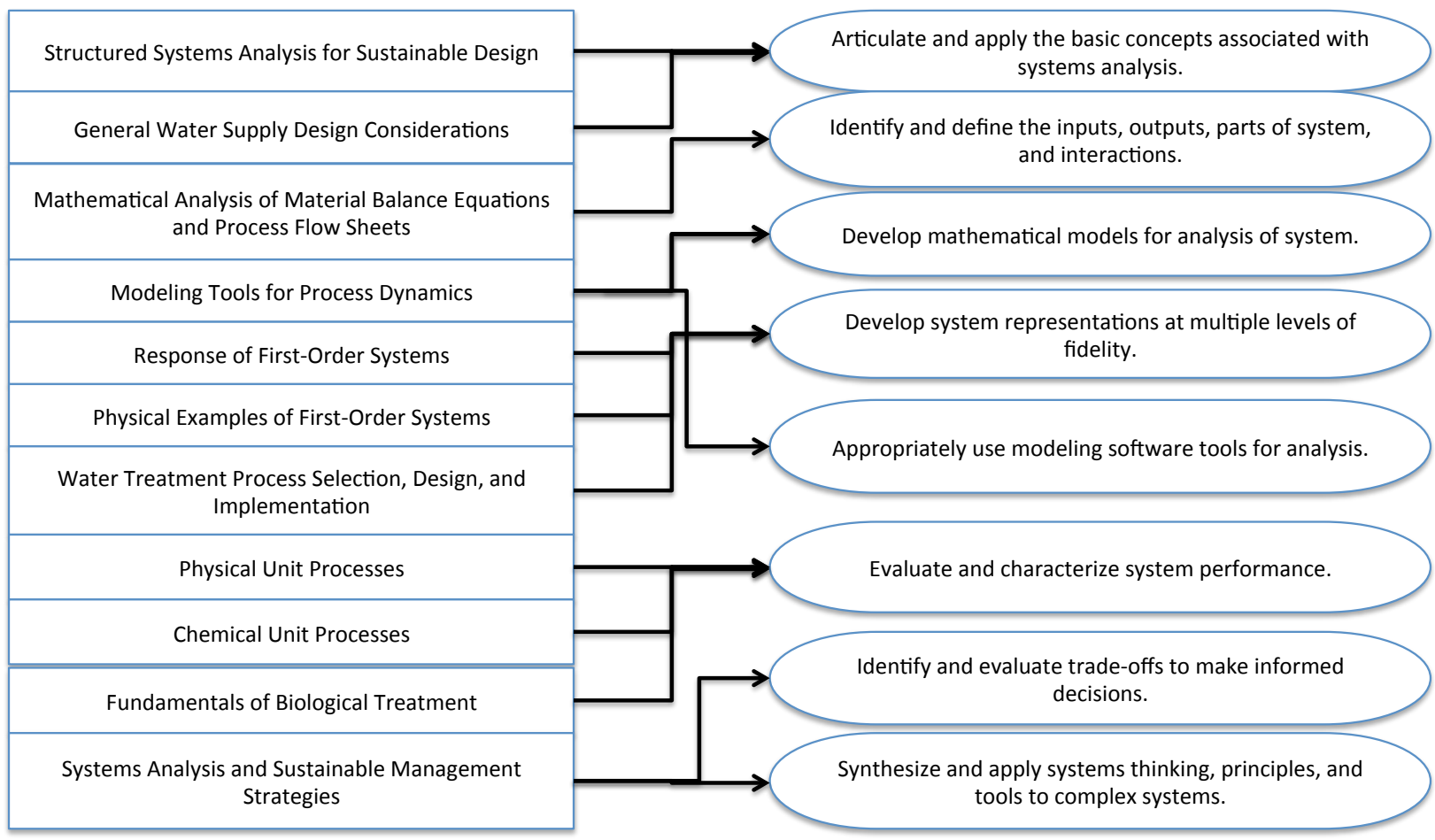

Figure 2: Course topics linked to ABET related outcomes for the earth systems engineering course 


\section{Place-based approach to describing the Chesapeake Bay through systems engineering}

The course met three days per week. The course topics listed above were typically covered in the first two lecture periods of the week, with the third meeting of the week being reserved for inclass project work. Additional weeks were allocated for exams and project presentation at the end of the semester. Readings and short homework problems were assigned for each topic. The lecture material included an overview of systems engineering concepts, examples of complex earth systems, and science-based model of water and ecological systems within the Chesapeake Bay. The project course score contributed to $20 \%$ of the course grade, the final exam comprised $35 \%, 2$ mid-term exams contributed $25 \%$ and homework contributed the final $20 \%$ of the course grade.

The place-based Chesapeake Bay project was described the first week of the course. The project was broken into seven significant intermediate project steps described in the following sections. On average, each project part was completed in two weeks. Typically students were allowed to peer-review each others work two to three days prior to submission of the assignment for grading. Student work was evaluated based upon the 100 point scale shown in Table 2 . The place-based project was divided into seven distinct assignments that are summarized below.

Table 2: Place-based project rubric

\begin{tabular}{|l|r|r|}
\hline \multicolumn{1}{|c|}{ Description of Evaluation } & $\begin{array}{c}\text { Possible } \\
\text { Points }\end{array}$ & $\begin{array}{c}\text { Cumulative } \\
\text { Score }\end{array}$ \\
\hline Part 1: System problem statement is clearly identified & 10 & 10 \\
\hline $\begin{array}{l}\text { Part 2: The degrees of freedom related to the problem statement are } \\
\text { correctly determined }\end{array}$ & 10 & 30 \\
\hline $\begin{array}{l}\text { Part 3: Preliminary mathematical model description relates } \\
\text { important variables and concepts }\end{array}$ & 10 & 40 \\
\hline $\begin{array}{l}\text { Part 4: The system boundaries are determined } \\
\text { Known variable are correctly determined from research }\end{array}$ & 10 & 45 \\
\hline \multicolumn{1}{|c|}{ Unknown variable are correctly identified } & 5 & 50 \\
\hline $\begin{array}{l}\text { Part 5: System inputs and outputs are identified and related to other } \\
\text { class components }\end{array}$ & 20 & 70 \\
\hline $\begin{array}{l}\text { Part 6: Model equations are appropriate and correctly solved \& } \\
\text { numerical calculations are correct }\end{array}$ & 20 & 90 \\
\hline $\begin{array}{l}\text { Part 7: Identify limitations and assumptions made during the } \\
\text { analysis }\end{array}$ & & 10 \\
\hline
\end{tabular}




\section{Part 1: Identify and Define Parts of a System}

This activity was a self-exploration activity. Students identified applications of engineering sciences for evaluation of issues related to the Chesapeake Bay. Students were instructed to use their personal experiences to identify a problem of interest. Students should:

- Explore their natural curiosity about Chesapeake Bay watershed.

- Think critically about how they can apply engineering science to identify a problem statement, create a mathematical representation of the problem, and solve the problem using mathematical and engineering relationships.

- Use the scientific method (hypothesis driven research) to refine their curiosity about the interconnected earth-system in which we all live.

Guiding questions included:

1. What questions do you have about the Chesapeake Bay system?

2. What one thing would you like to explore about the Chesapeake Bay system?

3. How would you explore your curiosity? (How would you find out more about your answer to question \#2)

4. What are potential sources that might provide information about your questions?

5. What does "good" or "reliable" information mean? How would you interpret and prioritize various sources of information?

6. List the keywords related to your area of interest.

7. Sketch your chosen component and the system boundaries.

\section{Part 2: Degrees of Freedom Analysis}

The objective of the second assignment was to apply basic engineering principles of problem definition to their system of choice. The assignment goals were to define a system process and related variables and identify gaps in the knowledge through a Degrees of Freedom analysis. Students were required to:

1. Sketch your Chesapeake Bay system.

2. Define processes (splitting, mixing, reactions, etc.) and show the streams entering and exiting your process(es).

3. Define and show the variables associated with your processes.

4. Set up a Degrees Of Freedom (DOF) analysis of your system. Determine the variable(s) you will need to calculate (solve for).

5. Determine how many variables will you need to define through research in order to make your calculations. 
Part 3: Develop a system model

The objective of assignment 3 was to develop a mathematical model for the chosen system. Students defined the relevant mathematical relationships and variables. The student requirements were to:

1. Use peer-reviewed sources to determine the values for all controlled variables and uncontrolled variables (note: this may over-constrain your system). Start with textbooks, journal articles, government docs, Chesapeake Bay Foundation (CBF) reports, or other resources as appropriate.

2. List the variables and reference for the sources of your information, a range of data for a given variable is appropriate.

\section{Part 4: System Boundaries}

The objective of assignment 4 was to develop systems representations at multiple levels of fidelity. Students created a working system-based model and communicate degrees of uncertainty. The student requirements were to:

1. Develop an electronic schematic that represents your Chesapeake Bay system.

a. For the known variables, provide references and ranges for reported values.

b. Describe in a short paragraph for each variable and report the values and expected ranges (high, mean, and low values if available).

c. For the unknown variables, define keywords for studies that might provide information about an unknown.

d. Describe what similar systems might be explored to help guide any assumptions you might be forced to make.

2. Describe the boundary conditions of your system and the inherent assumptions required to define the system.

3. What related conditions beyond the boundary of the system of study might impact the results of the system analysis? Illustrate these potential conditions and impacts on the schematic.

\section{Part 5: Synthesize information about complex systems}

The objective of assignment 5 was to synthesize and apply systems thinking, principles and tools to complex systems. In this activity, students performed a "brainstorming" activity in class, documented by sketching the information requested below. The goal was to expand the knowledge they had about activities in the Chesapeake Bay watershed and relate those activities relate to their specific model. Peer-review was used to refine the system models. The information from multiple students was used to improve their individual work upon reflection, communication and refinement of the model developed in Part 4. The student requirements for this assignment were to: 
1. Identify how their "black-box" model is linked to five other "black boxes" being developed by peers in the class. Students mus speak to more than five different people to find five systems that share a well-defined link.

a. Re-draw the boundary conditions.

b. Show all the systems the student interacted with in class in each drawing - some may be linked, some may not be.

i. For each system, define all possible the variables that relate to each individual system and identify the names of the class peers related to each system.

ii. Illustrate the variables being analyzed by the interacting systems.

iii. Illustrate the variables that have been ignored by choice in the interacting systems.

2. Students should add the interacting "black-boxes" to the schematic that illustrates their system. Students should identify by name the source of information for the linked black boxes - this creates a new system. Students should identify known and unknown variable in the system and changes throughout the system of study. Note: this may require additional interactions beyond classroom time, so students might benefit from seeking permission to contact classmates outside of the normal class period.

\section{Part 6: Chesapeake Bay Modeling}

The objective of assignment 6 was to illustrate the principles of reactor design and application of those principles to modeling a complex Earth system. Students determined the type of model reactor that most closely represented the chosen system. Students used their model to predict what happened to the chosen system given a perturbation to the system (i.e. changing one or more variables). The student requirements for this assignment were to answer the following:

1. What variables are constrained and what variables may fluctuate in your system? Describe the scenario you are going to model. Include a range of likely conditions that should be considered. Include appropriate units.

2. What type of reactor/reactions may be used to model your system?

a. Can you define your system as a batch, CSTR or PFR reactor? Explain how.

b. Can you apply chemical kinetics of microbial growth kinetics to your model? Explain how and describe the reaction order if applicable.

3. Show the mass balance model of your process, use the variable definitions above?

4. What are the assumptions required to solve the mass balance? Describe and list the assumptions, for example, steady-state, conservative substance, average mass of an organism, etc.

5. Write a homework style questions based upon one likely scenario. Show the solution to this example scenario - include all relevant steps

6. Enter your work into either an Excel or MathCad program and show solutions to a range of potential scenarios. You will need to submit your results and an electronic version of 
your solution. You must state the reasons for the chosen ranges; examples might include low-medium-high range of input data reported in the literature, season variations, etc.

a. Represent your findings graphically.

b. Document your electronic file so that the user can easily interpret it.

\section{Part 7: Reflection}

The objective of assignment 7 was to identify and evaluate trade-offs to make informed decisions about managing resources in the Chesapeake Bay watershed. Students discussed and provided a critique of a peer's system model. The student requirements for this assignment were to answer guided questions in peer groups. Examples questions included:

1. Is the question you started with the question to which you developed an answer?

2. What are the Key elements in searching for data?

3. How would policy makers use the information presented in the class Chesapeake Bay Watershed model to create policy for the Bay?

\section{Results}

Students integrated their own experiences and relationships to the Chesapeake Bay by defining the earth systems. Examples were varied and included analysis of trout populations in headwater streams, impacts from agriculture and residential development in piedmont regions of the watershed, and several examples of personal use of the bay as well as system-wide impacts to fish and oyster populations in the Chesapeake Bay.

Several examples of the work are illustrated below in Figures 3 to 7. The sample work shown here is largely representative of the average student work. The work also meets or surpasses the expectations associated with the assignments. Several different project concepts/submissions are shown in order to illustrate the diversity of topics chosen in the course. Since the examples built upon prior work, the examples shown are the composite submissions of several earlier assignments (Parts $1-4)$.

The following example illustrates how typical submissions to Parts 1 of the project have defined the problem. In this example, a basic problem statement is presented first. The system parameters that impact the solution are grouped into a range of possible conditions (High, Average, Low). The functional units associated with each parameter are also defined. 


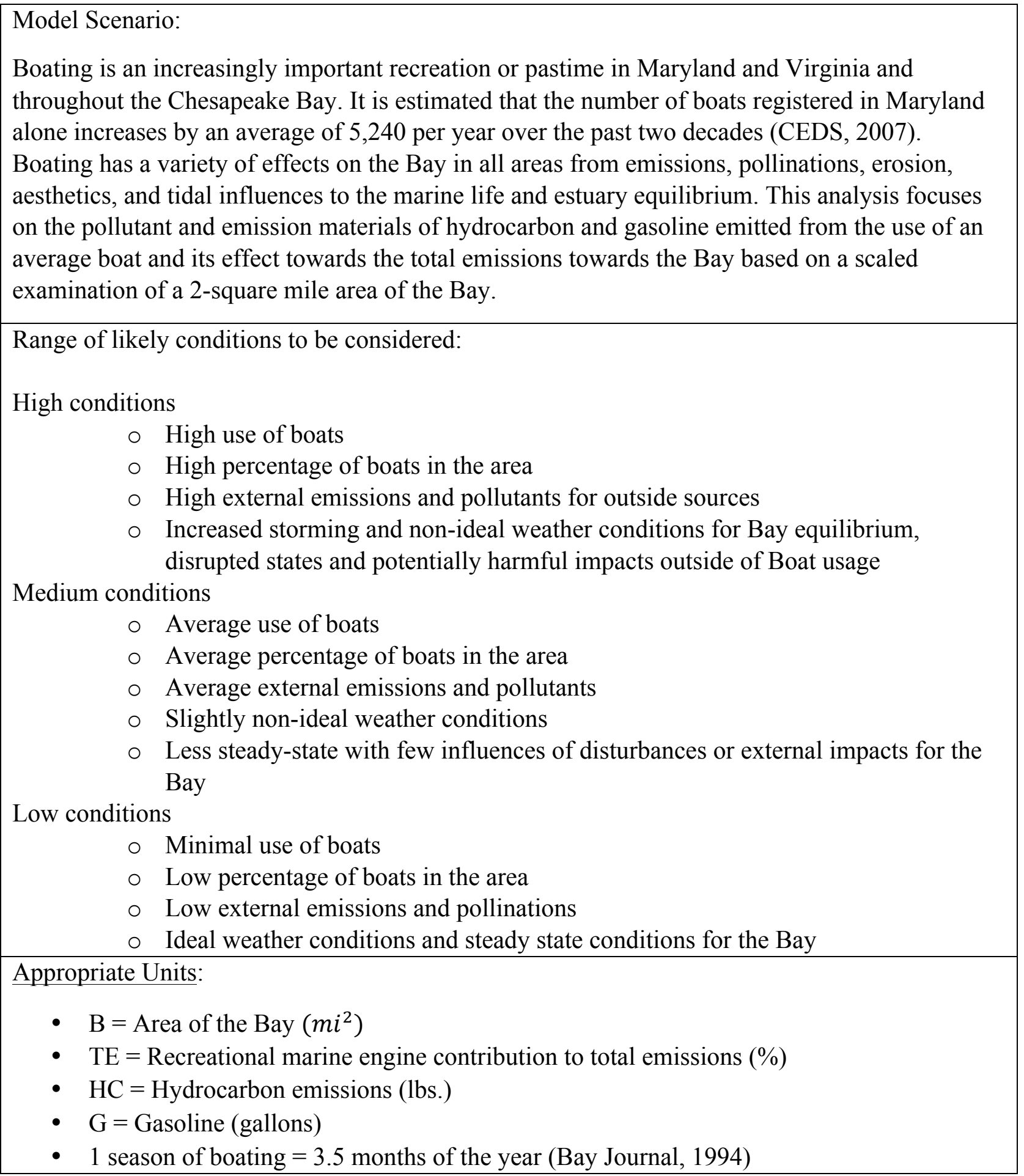

Figure 3: Student example work illustrating Part 1: Identify and Define Parts of a System 
The complex nature of the Chesapeake Bay and interrelationships among various factors are illustrated in Figures 4 and 5. The schematics shown below illustrate the connections defined and created by the students in "Part 5: Synthesize information about complex systems". Figure 4 illustrates the range of impacts upon rockfish (also called striped bass) populations in the Chesapeake Bay. The student work illustrates connections with other evaluations being conducted in the course. The example work also illustrates and defines the variables associated with each evaluation, ranges of important variables and the units associated with the variables of concern. The examples and related analysis is not meant to be a complete working model of all interactions within the Chesapeake Bay, instead the work illustrates attainment of several course objectives, including the ability to:

- Articulate and apply the basic concepts associated with systems analysis.

- Identify and define the inputs, outputs, parts of system, and interactions.

- Develop system representations at multiple levels of fidelity.

- Develop mathematical models for analysis of system.

The second example shown in Figure 5 illustrates the attainment of similar objectives for relating nutrient loading to blue crab populations in the Chesapeake Bay. Figure 6 illustrates student work that exemplifies the principles of reactor design and modeling a complex Earth system. Part 6.1 of the project, Chesapeake Bay Modeling, requires students to determine the variables that are constrained and variables that fluctuate in the system. 


\section{ASEE Annual Conference}

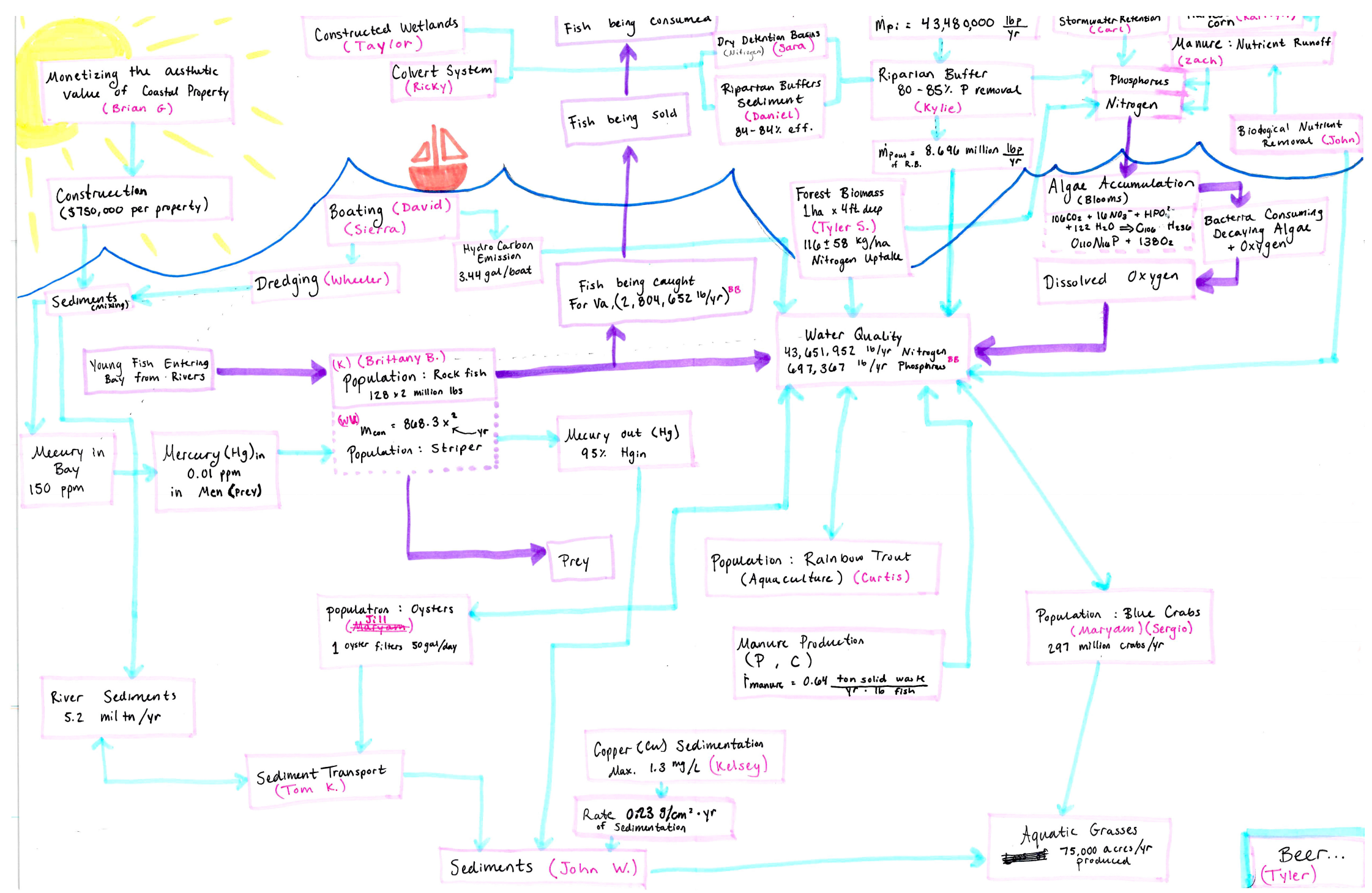

Figure 4: Student example work illustrating system connections, variables and data for modeling rockfish populations in the Chesapeake Bay 


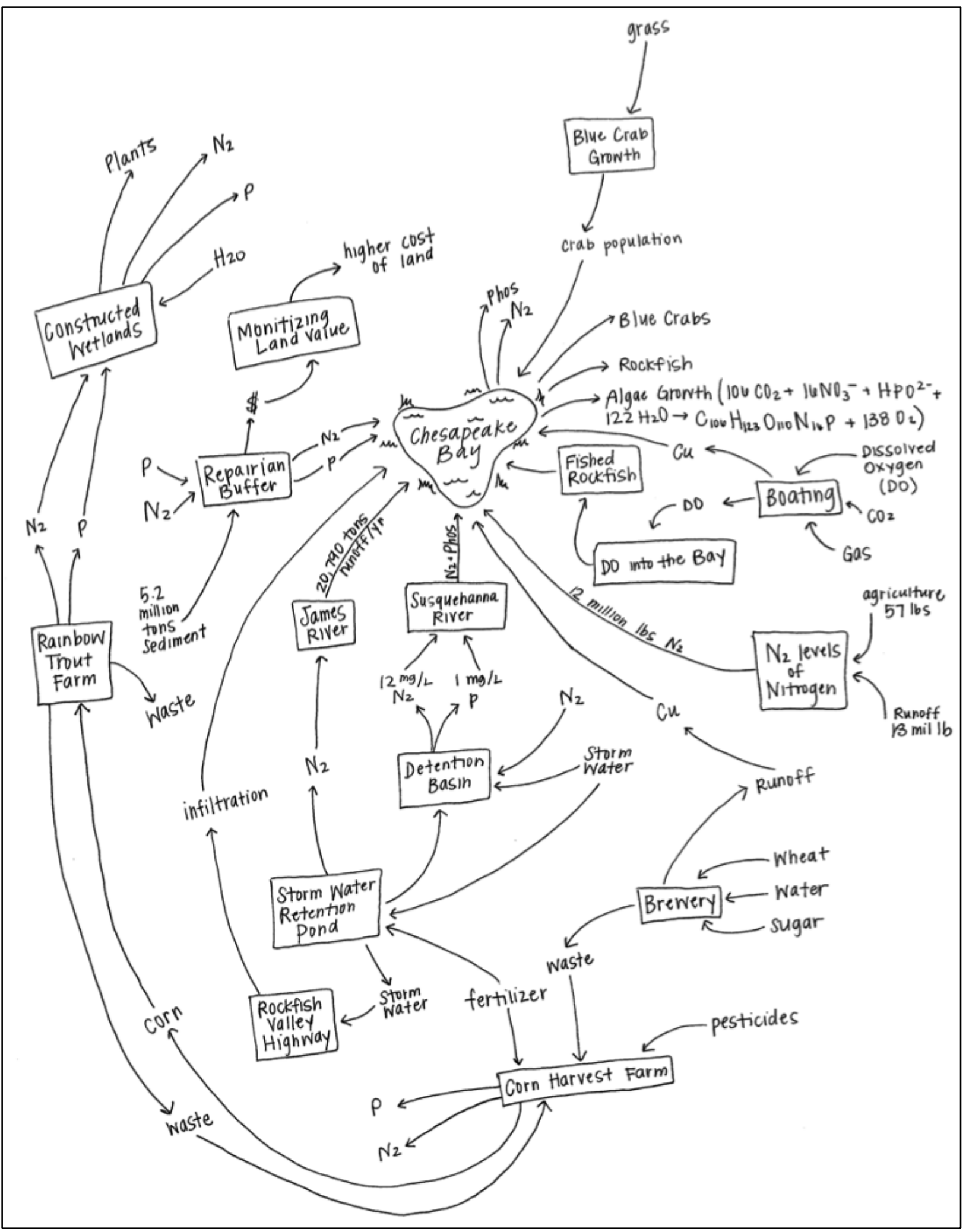

Figure 5: Student example work illustrating system connections, variables and data for modeling the nutrient loading relationship and the blue crab populations in the Chesapeake Bay 


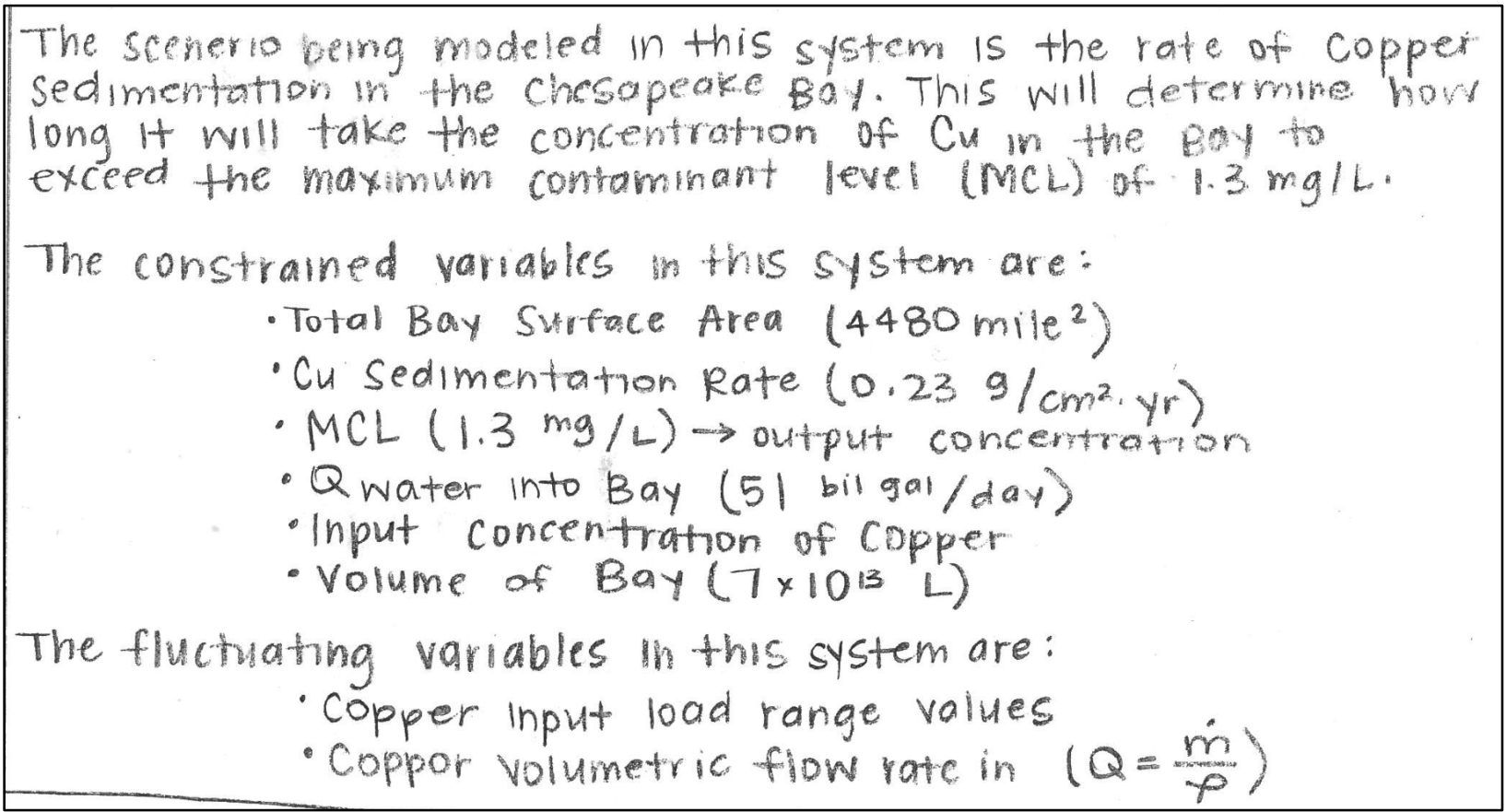

Figure 6: Student example defining the variables in a model system.

Students were required to utilize empirical or theoretical equations to model one or more variables of their chosen system. Figure 7 illustrate a student applying mass balance and chemical transformation principles in order to relate nutrient loading from agricultural to algae production in the Chesapeake Bay. Part 6 of the model illustrates the students' abilities to:

- Evaluate and characterize system performance for one or more variables in the model system.

- Appropriately use modeling software tools such as Excel and MathCad to analyze a simplified system.

- Identify and evaluate trade-offs to make informed decisions by identifying critical variables in the system.

Students presented their work during the last week of class and were required to offer a reflection on the projects and the Chesapeake Bay system. Project part 7 provided evidence that students were able to synthesize and apply systems thinking, principles, and tools to solve mathematical and engineering representations of complex systems. 


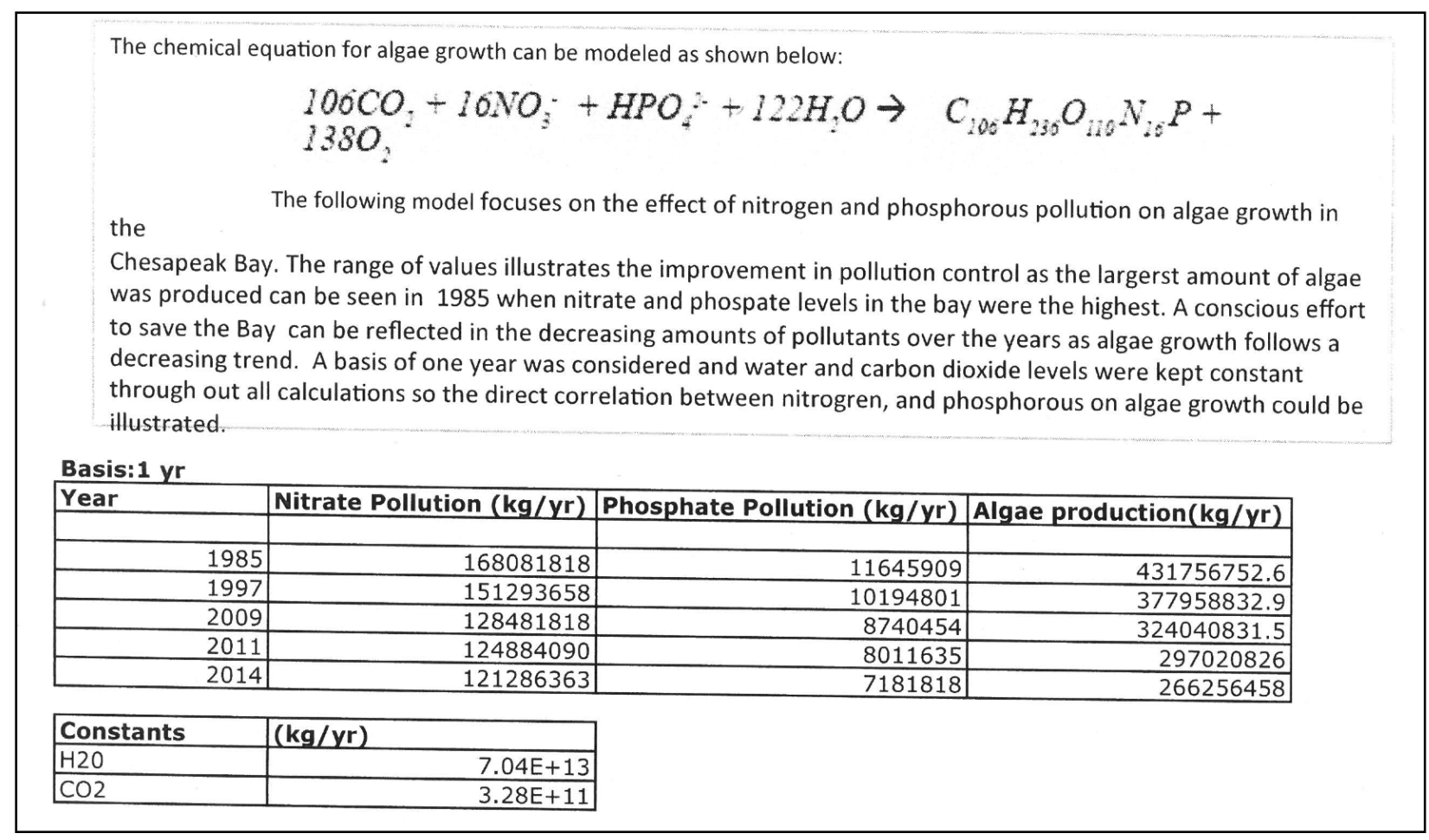

Figure 7: An example utilizing chemistry and mass balance principles to relate nutrient loading to algae production in the Chesapeake Bay.

Overall 82 percent of students met the objectives associated with the place-based project. The mean percentage score for all seven parts of the project was $86.7 \%$, with scores ranging from a low of $19 \%$ to a high of $100 \%$. Students appear to have performed better on the place-based project than on homework (mean average $=84.2 \%$ ), the final exam (mean average $=79.7 \%$ ), and quizzes (mean average $=78.9 \%$ ). The limited data suggests that performance generally increased as the project moved towards completion of the analytical assignments as shown in Figure 8. (It is noted via the range shown that performance did not increase for every individual student.) This supports the general observation that students which struggled early the course with the openended assignment, gained insight and confidence in completing the project as they became more familiar with the concept matter and project objectives. Just as important the trend in meeting the objectives and comprehension of the course outcomes increased throughout the course, indicating the project help students "put it all together" as indicated by student comments.

The place-based project was well received by the students at the completion of the course as evidenced by student comments on aspects of the course the liked best:

"The different spin on the class made it interesting"

"Allowing us to choose a system that I am personally interested in to analyze"

"The Deep learning exercise. This helped me put everything together that we learned in the course" 
"The Chesapeake Bay project helped me to understand the concepts being taught in class"

"Course style, lots of independent work that aligns with main concepts"

"I like that it expanded my perception of what engineers do. It also related sustainability, thermo fluids, math modeling, and other sciences together into a more worldly or real problem solving approach."

"I liked taking an engineering approach to studying the Chesapeake Bay. This increased the interest of the class by using a real world example"

"I liked linking mathematical modeling with environmental systems to understand effects of pollutants and changes in ecosystems."

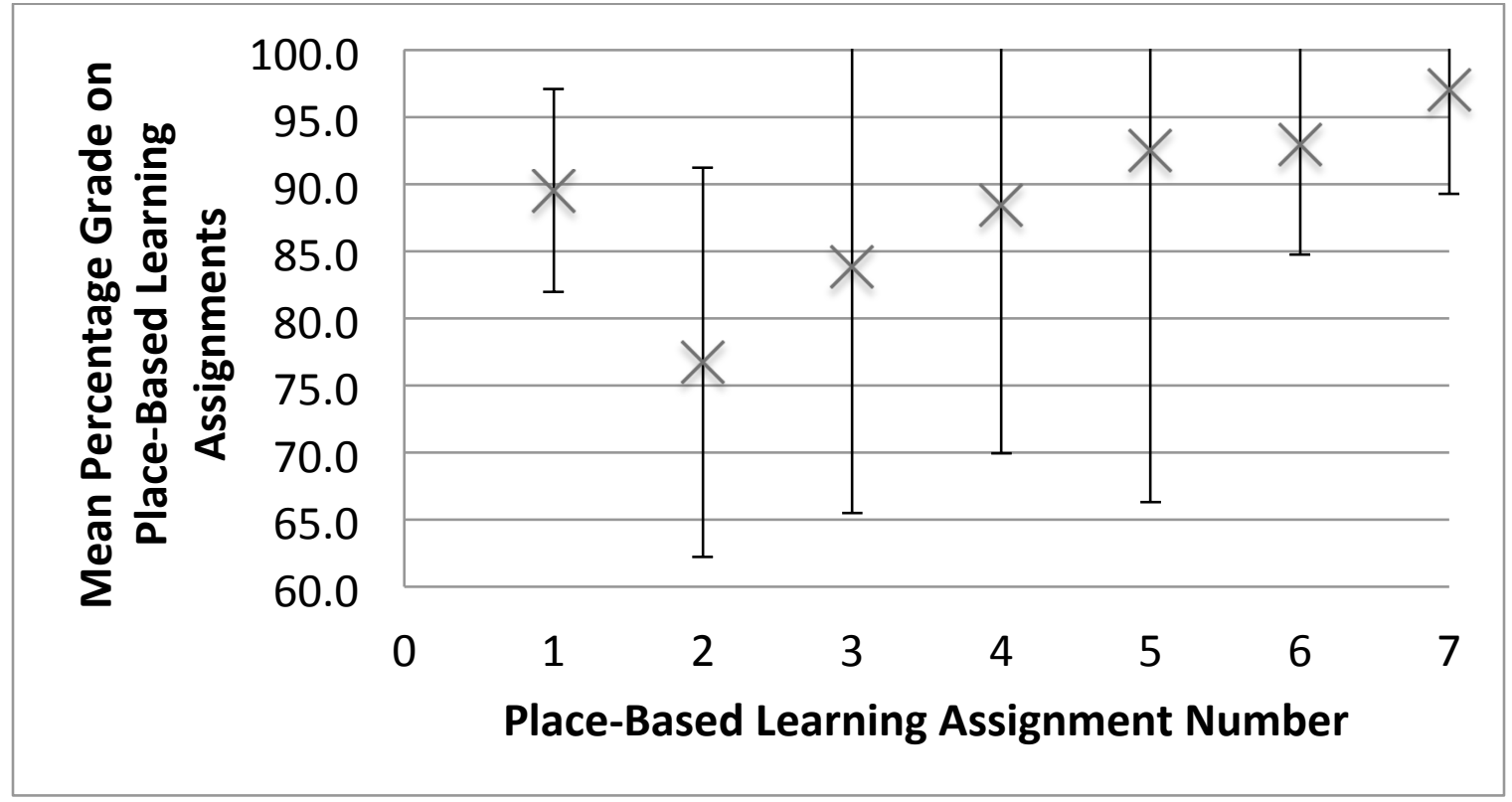

Figure 8: Increase in student performance on the open-ended project over the course of the semester.

The aspects of the course the students reported to be most challenging included:

"Not understanding if we were completing assignments properly"

"In the beginning the direction of the course was unclear."

The following comments represented suggestions by the students for improving the class:

"Laying out the differences this course would have from the other classes. The focus on the Chesapeake Bay threw me off at first." 
"Having a list of topics for students to choose from regarding the class project and having known resources for students to review for research."

The course objectives were assessed through the place-based project, the final exam and students self-reported their self-assessment of meeting the course objectives as shown in Table 3.

Table 3: Assessment of course outcomes from student self-reporting, place-based project evaluation and final exam.

\begin{tabular}{|c|c|c|c|}
\hline \multirow[t]{2}{*}{ Description of the Course Objective } & \multirow{2}{*}{$\begin{array}{l}\text { Student } \\
\text { self- } \\
\text { reported } \\
\text { attainment }\end{array}$} & \multicolumn{2}{|c|}{$\begin{array}{l}\text { Percent of students } \\
\text { attaining objects as } \\
\text { measured by }\end{array}$} \\
\hline & & $\begin{array}{c}\text { Place-based } \\
\text { project }\end{array}$ & $\begin{array}{l}\text { Final } \\
\text { exam }\end{array}$ \\
\hline $\begin{array}{l}\text { 1. Articulate and apply the basic concepts associated with } \\
\text { systems analysis. }\end{array}$ & $78 \%$ & $94 \%$ & \multirow{8}{*}{$91 \%$} \\
\hline $\begin{array}{l}\text { 2. Identify and define the inputs, outputs, parts of system, } \\
\text { and interactions. }\end{array}$ & $85 \%$ & $79 \%$ & \\
\hline $\begin{array}{l}\text { 3. Develop system representations at multiple levels of } \\
\text { fidelity. }\end{array}$ & $81 \%$ & $79 \%$ & \\
\hline 4. Develop mathematical models for analysis of system. & $60 \%$ & $79 \%$ & \\
\hline 5. Evaluate and characterize system performance. & $79 \%$ & $82 \%$ & \\
\hline 6. Appropriately use modeling software tools for analysis. & $80 \%$ & $94 \%$ & \\
\hline $\begin{array}{l}\text { 7. Identify and evaluate trade-offs to make informed } \\
\text { decisions. }\end{array}$ & $74 \%$ & $91 \%$ & \\
\hline $\begin{array}{l}\text { 8. Synthesize and apply systems thinking, principles, and } \\
\text { tools to complex systems. }\end{array}$ & $81 \%$ & $91 \%$ & \\
\hline
\end{tabular}

The majority of students ( $82 \%$ ) demonstrated the required knowledge to meet the overall course objectives (scoring $70 \%$ or greater on graded project assignments and the final exam). Students may have reported lower attainment rates, due to receiving lower than expected grades - in other words some students associated attainment of the objectives by receiving a grade greater than $90 \%$ for the course. The instructor measure for demonstration of the objectives is based a score greater than $70 \%$. Generally the most difficult objective based upon student self-assessment and project-based assessment was to create a mathematical model of a complex system. It is a credit to the students that they were able to identify this objective as a very difficult task. For example, modeling the Chesapeake Bay has been a decades long scientific endeavor to which teams of scientists have dedicated their careers. The author believes the students are better able to assess the challenges inherent in modeling earth systems and genuinely have become more aware of individuals limitations and approaches to complex systems modeling. None-the-less, students 
were largely satisfied with the place-based project approach to learning the subject, even though students were challenged with sorting through a complex scenario at the beginning of the course.

\section{Summary}

The objectives of the systems engineering course were tailored to personal interests through a placed-based project related to the Chesapeake Bay. The inclusion of the place-based project helped ensure student engagement throughout the entirety of the semester. Evidence showed improvement of students understanding of systems engineering concepts continued to develop through the completion of the course.

Students were encouraged to explore systems concepts. Students reported they initially found the open-ended format challenging. They reported the lack of clearly marked roadmaps or similar examples for defining their solutions was an unaccustomed challenge. A few students suffered serious anxiety related to the open-ended problem and requirements to create their own original work.

The student work shown above illustrates the critical thinking processes the students engaged in while working on the project. It is important to note that the relationships developed were all original concepts, since each participant in the class determined the relevant subjects. Since all the work was original, based on class developed systematic description of the bay, there was no concern for students relying on electronic resources. Students self-reported they often become dependent upon electronic resources (Chegg, myhomeworkhelp.com, etc.) that minimize critical thinking. By creating open-ended projects that are based upon student's local knowledge of place, critical thinking can be encouraged and the pitfalls of electronic dependency can be avoided. By the completion of the course, students reported a high degree of satisfaction and gained confidence in the ability to investigate problems of their own choosing. Approximately $82 \%$ of students completed the course objectives through the open-ended place-based investigation of the Chesapeake Bay System.

\section{References}

1. Allenby, B.R. 2002. Earth systems engineering and management. IEEE Technology in Society. 19(4)10-24.

2. Allenby, B. 2007. Earth Systems Engineering and Management: A Manifesto. Environmental Science and Technology. 41(23):7960-7965

3. Amadei, B. 2015. A systems approach to modeling community development projects. Momentum Press. New York, NY.

4. Blanc, E., K. Strzpek, A. Schlosser, Jacoby, H. A. Gueneau, C. Fant, S. Rausch, and J. Reilly. 2013. Analysis of US water resources under climate change. MIT Joint Program on the Science and Policy of Climate Change. 
5. Brandt, L.A., J. Beauchamp, J.A. Browder, M. Cherkins, A. Clarke, R.F. Doren, P. Frederick, E. Gaiser, D. Gawlik, L. Glenn, E. Hardy, A.L. Haynes, A. Huebner, K. Hart, C. Kelbie, S. Kelly, J. Kline, K, Kotun, G. Liehr, J. Lorenz, C. Madden, F.J. Mazzotti, L. Rodgers, A. Rodusky, D. Rudnick, B. Sharfstein, R. Sobszak, J. Trexler, A. Volety. 2014. System-wide indicators for Everglades restoration. Technical Report. 111p.

6. Brunn, S. D. 2011. Engineering Earth: The Impacts of Megaengineering Projects. Springer. New York, NY. 2266p.

7. Chesapeake Bay Foundation. 2015. 2014 State of the Bay report. Chesapeake Bay Foundation. Annapolis MD. 20pp.

8. FAO. 2011. The state of the world's land and water resources for and agriculture (SOLAW) - Managing systems at risk. Food and Agriculture Organization of the United Nations, Rome and Earthscan, London.

9. Global Water Partnership. 2004. Catalyzing Change: A handbook for developing integrated water resources management (IRWM) and water efficiency strategies. Elanders, Norway, 2004.

10. Gorman, M.E. 2005. Earth systems engineering management: human behavior, technology and sustainability. Resources, Conservation and Recycling. 44(2005)201-213.

11. Gorman, M.E., Allenby, B. Mehalik, M.M., Hall, K. 2003. Earth systems engineering management: a course for students from multiple disciplines. World Transaction on Engineering Technology Education 2(1)29-32.

12. Gruenewald, D.A. 2003. The best of both worlds: A critical pedagogy of place. Educational Researcher. 32(4)3-12.

13. Gruenewald, D.A. 2008. Place-based education in the global age: Local diversity. Psychology Press. Hove, East Sussex. p xiii - xxiii.

14. Habibian, M. 2011. Critical Issues and Sustainability Challenges for a Large Metropolitan Water-Wastewater Utility. Sustainability of Water resources, National Academy of Engineering, winter, 2011. p. 29-36.

15. NASA. 2003. Earth Science Enterprise Strategy. NASA Headquarters. Washington, DC. NP-2003-01-298-HQ.

16. Passino. K.M. 2016. Humanitarian Engineering: Advancing Technology for Sustainable Development. Edition 3, Bede Publishing, Columbus, Ohio

17. Pyke, C.R., R.G. Najjar, M.B. Adams, D. Breitburg, M. Kemp, C. Hershner, R. Howarth, M. Mulholland, M. Paolisso, D. Secor, K. Sellnar, D. Wardrop, and R. Wood 2008. Climate Change and the Chesapeake Bay: State-of-the-Science Review and Recommendations. A report from the Chesapeake Bay Program Science and Technical Advisory Committee (STAC), Annapolis, MD. 
18. Schaub, G. and Turek, T. 2011. Energy Flows, Material Cycles and Global Development. Springer. New York, NY. 204p.

19. Semken, S. and Freeman, C. B. 2008. Sense of place in the practice and assessment of place-based science teaching. Sci. Ed., 92: 1042-1057.

20. Striebig, B., Ogundipe, A., and Morton, S. 2014. Lessons in implementing sustainability courses into the engineering curriculum. 121st ASEE Annual Conference \& Exposition, June 15-18th, 2014, Indianapolis, IN.

21. Striebig, B., A. Ogundipe and M. Papadakis. 2016. Engineering Applications in Sustainable Design and Development: 1st Edition. Cengage Publishing. Boston, MA. 746p.

22. Striebig, B. 2016. Applying US EPA sustainability criteria to capstone design. Engineering for Sustainability. ASEE SE Section Annual Conference, March 13-15, 2016. Tuscaloosa, AL.

23. Striebig, B. and Morton, S. 2016. A Sustainability Indicators Based Curriculum.

Engineering for Sustainability. ASEE SE Section Annual Conference, March 13-15, 2016.

Tuscaloosa, AL.

24. US Army Corps of Engineers. 2014. Building strong collaborative relationships for a sustainable water resources future: Understanding integrated water resources management (IWRM). Civil Works Directorate. Washington DC.

25. USEPA. 2012. Safe and Sustainable Water Resources: Strategic Research Action Plan 2012 -2016 .

26. VA DEQ. 2014. Status of Virginia's Water Resources: A report on Virginia's water resources management activities. Virginia Department of Environmental Quality, Office of Water Supply.

27. van der Gun, J. 2012. Groundwater and Global Change: Trends, Opportunities and Challenges. United Nations Educational, Scientific and Cultural Organization, Paris, France.

28. Woodhouse, J.L., Knapp, C.E. 2000. Place-based curriculum and instruction: Outdoor and environmental education approaches. ERIC Digest, ED448012. 